\title{
IMPLEMENTASI MODEL DIAMOND PORTER DALAM MEMBANGUN KEUNGGULAN BERSAING PADA KAWASAN AGROWISATA KEBUN BELIMBING NGRINGINREJO BOJONEGORO
}

\author{
Ety Saraswati ${ }^{1}$, Aleria Irma Hatneny ${ }^{2}$, Andi Normala Dewi ${ }^{3}$ \\ ${ }^{1}$ Fakultas Ekonomi Dan Bisnis Universitas Islam Malang \\ Email: etysaraswati@unisma.ac.id \\ ${ }^{2}$ Fakultas Ekonomi Dan Bisnis Universitas Islam Malang \\ Email: aleriairma189@gmail.com \\ ${ }^{3}$ Fakultas Ekonomi Dan Bisnis Universitas Islam Malang \\ Email: andinormala1887@gmail.com
}

\begin{abstract}
Abstrak
Penelitian ini bertujuan untuk menguji analisis keunggulan kompetitif melalui model berlian Porter di Agrotourism Ngringinrejo Bojonegoro. Metode penelitian yang digunakan adalah deskriptif dengan pendekatan kualitatif. Teknik pengumpulan data dilakukan dengan wawancara, observasi dan dokumentasi. Hasil menunjukkan penentu penting dalam keunggulan kompetitif Agrotourism Ngringinrejo Bojonegoro, sesuai dengan model pengangkut berlian, terdiri dari kondisi faktor; kondisi permintaan; struktur perusahaan, strategi dan persaingan; industri terkait dan pendukung; dan peran pemerintah. Perbedaan masing-masing penentu keunggulan kompetitif memiliki implikasi untuk keunggulan keberlanjutan yang didasarkan pada empat dikotomi utama, terdiri dari keterlibatan pemerintah, struktur kepemilikan, pasar (yang dimasukkan oleh industri), dan perluasan area lain yang tidak terkontrol (urban sprawl). ). Formulasi strategi generik yang sesuai untuk Agrowisata Ngringinrejo adalah strategi fokus, dengan membangun kapasitas untuk melakukan inovasi dan penelitian di luar peningkatan produktivitas pertanian, serta membangun fasilitas wisata buatan untuk mendukung daya saing. Kata kunci: Model Keunggulan Kompetitif Pariwisata, Keunggulan Kompetitif Berkelanjutan, Strategi Generik
\end{abstract}

\section{Abstract}

This study aims to examine the competitive advantage analysis through the Porter's diamond model in Agrotourism Ngringinrejo Bojonegoro. The research method used is descriptive with qualitative approach. Data collection techniques are done by interview, observation and documentation. The results showed important determinant in the competitive advantage of Agrotourism Ngringinrejo Bojonegoro, in accordance with the diamond porter model, consist of factor conditions; demand conditions; firms structure, strategy and competition; related and supporting industries; and government roles. The difference of each determinant of competitive advantage has implications for sustainability advantages which based on four main dichotomies, consist of government involvement, ownership structure, market (which is entered by the industry), and expansion of other areas that are not controlled (urban sprawl). The generic strategy formulation that is suitable for Agrotourism Ngringinrejo is a focus strategy, by building capacity to carry out innovations and research beyond increasing agricultural productivity, as well as building artificial tourism facilities to support competitiveness.

Keywords: Tourism Competitive Advantage Models, Sustainable Competitive Advantage, Generic Strategies 


\section{PENDAHULUAN}

Pariwisata merupakan salah satu sektor andalan dalam pembangunan perekonomian nasional. Kontribusi sektor pariwisata dinilai cukup besar, baik terhadap peningkatan PDB, devisa negara, maupun penciptaan lapangan pekerjaan, sehingga menempatkan pariwisata sebagai backbone perekonomian bangsa yang memiliki banyak keunggulan kompetitif dan keunggulan komparatif. Data hasil laporan kinerja Kementrian Pariwisata tahun 2016 menunjukkan bahwa sektor pariwisata telah menyumbangkan 10\% PDB nasional, dimana secara nominal merupakan yang tertinggi di ASEAN. Selain itu, pariwisata juga termasuk peringkat ke-empat sebagai penyumbang devisa nasional, yakni sebesar 9,3\% dibandingkan industri lainnya. Penerimaan devisa pariwisata tersebut terus mengalami peningkatan dan bahkan dinilai yang tertinggi, yakni sebesar $13 \%$ dibandingkan industri minyak dan gas bumi, batubara, serta minyak kelapa sawit yang pertumbuhannya cenderung menurun (negatif). Dalam hal penciptaan lapangan pekerjaan, data Kementrian Pariwisata (2016) menunjukkan bahwa jumlah penyerapan tenaga kerja ditahun 2016 mencapai hingga 12 juta orang, yang hal ini terutama disebabkan oleh adanya kemudahan investasi dan meningkatnya jumlah usaha pariwisata.

Pariwisata disinyalir sebagai industri dengan pertumbuhan tercepat, tidak hanya di Indonesia saja, namun juga di dunia. Pengembangan pariwisata sangat penting terutama bagi negara berkembang, karena hal ini akan memberikan dampak positif dalam upaya meningkatkan nilai suatu wilayah geografis tertentu serta dalam upaya mendorong revitalisasi suatu wilayah geografis yang telah kehilangan daya tariknya (Ryan, 1991). Manfaat industri pariwisata terutama dirasakan oleh para pemangku kepentingan (stakeholders), diantaranya pemerintah, pemerintah daerah, dunia usaha, dan masyarakat (baik sebagai wisatawan maupun sebagai tuan rumah), sehingga masing-masing pihak tersebut memiliki peran dalam menjalankan industri pariwisata (Ismayanti, 2010). Pariwisata dikatakan mempunyai dorongan yang luar biasa hingga dapat membuat masyarakat setempat mengalami siklus dalam kehidupan. Oleh karena itu, keberhasilan pengembangan pariwisata dapat ditentukan oleh faktor-faktor yang mempengaruhi daya saing wisatanya, baik dari faktor dukungan sumber daya destinasi (keunggulan komparatif) maupun dari kapasitas untuk menggunakan sumber daya (keunggulan kompetitif).

Goeldner dan Ritchie (2007) mengungkapkan bahwa mencari pengalaman dan kepuasan yang bersifat psikis dan fisik merupakan alasan wisatawan berkunjung ke suatu destinasi. Kemudian Antariksa (2012) menjelaskan bahwa sebelum sebuah destinasi dikembangkan, motivasi merupakan faktor penting yang harus dipahami yang melatarbelakangi seseorang untuk melakukan perjalanan. Berdasarkan kedua pendapat tersebut, dapat dikatakan bahwa pengembangan destinasi pariwisata akan menjadi lebih mudah apabila para stakeholders dapat melakukan identifikasi mengenai potensi daya tarik wisata suatu wilayah secara tepat dan mampu memahami motivasi para wisatawan. Untuk dapat memaksimalkan pencapaian hasil pengembangannya, industri pariwisata 
harus dapat menjadi industri yang menguntungkan, baik untuk saat ini maupun dimasa mendatang, sehingga pengembangan dan pengelolaannya harus sesuai dengan paradigma daya saing baru (Ritchie dan Crouch, 1993).

Di masa lalu, upaya pengembangan obyek pariwisata hanya diarahkan untuk memiliki sumber daya berupa turis, gaji rendah, nilai tukar yang menarik, dan lain-lain sehingga suatu obyek pariwisata dapat bersaing dan sukses dalam industri pariwisata internasional (Bordas, 1994). Namun, sejalan dengan adanya pergeseran paradigma, saat ini daya saing dianggap sebagai faktor terpenting yang menentukan keberhasilan jangka panjang suatu organisasi, industri, wilayah dan negara (Kozak dan Rimmington, 1999). Pendekatan ini memunculkan perumusan serta implementasi strategi dan kebijakan yang ditujukan terutama untuk merangsang volume wisatawan. Secara empiris Poon (1993) telah menunjukkan bahwa untuk mendapatkan keuntungan jangka panjang dan patronase berkelanjutan dalam sebuah obyek wisata, penting untuk memiliki suatu keunggulan kompetitif.

Teori keunggulan kompetitif Porter pada dasarnya menjelaskan keberhasilan sebuah negara dalam industri tertentu (Ribes, et al. 2011). Dalam konteks pariwisata, model keunggulan kompetitif ini dapat digunakan sebagai strategi dalam pengembangan kawasan pariwisata yang berdaya saing di pasar pariwisata. Menurut teori pertukaran sosial (social excange theory), pembangunan akan diterima masyarakat apabila mempunyai dampak positif, dengan kata lain, manfaat yang diterima lebih besar dibanding pengorbanan atau biaya yang dikeluarkan. Masyarakat cenderung menolak dampak negatif dan menerima dampak positif pariwisata (McGehee dan Andereck, 2004; Wang dan Pfister, 2006). Agar pengembangan suatu kawasan pariwisata mempunyai manfaat berkelanjutan, terlebih dahulu diperlukan model strategi pengembangan kawasan pariwisata yang berdaya saing dan berkelanjutan.

Agrowisata Belimbing Ngringinrejo Bojonegoro merupakan salah satu kawasan wisata perkebunan yang berlokasi di Desa Ngringinrejo Kecamatan Kalitidu Kabupaten Bojonegoro Jawa Timur. Daerah yang dulunya dikenal rawan bencana dan endemic poverty sekarang berubah menjadi daerah dengan pertumbuhan ekonomi yang tinggi. Sampai dengan saat ini, total luas kebun belimbing dikawasan agrowisata adalah 20.5 hektar, dengan jumlah tanaman sebanyak 10.250 pohon, kapasitas produksi sebesar $80 \mathrm{~kg}$ per pohon per tahun, dan frekuensi panen sebanyak empat kali setiap tahun (masa panen tiga bulan). Kontribusi utama dari adanya agrowisata belimbing ini adalah meningkatnya perekonomian di Bojonegoro, khususnya perekonomian masyarakat sekitar kawasan agrowisata. Sebagian besar warga bekerja sebagai petani belimbing, sementara sebagian lainnya sebagai pedagang buah belimbing dan pengatur tempat parkir bagi para wisatawan. Melalui wadah Kelompok Sadar Wisata (Pokdarwis), masyarakat diarahkan untuk dapat mengelola kebun dengan baik, sehingga selain bertujuan untuk menghasilkan buah belimbing yang berkualitas dalam berbagai varietas, masyarakat juga 
mampu membuat meningkatkan nilai ekonomis dari belimbing melalui produk olahan seperti sari buah, sirup, dan dodol.

Semakin pesatnya perkembangan industri pariwisata, baik di tingkat nasional maupun regional, destinasi pariwisata dihadapkan pada persaingan yang cukup ketat. Persaingan dapat menyebabkan pengunjung memperoleh banyak pilihan, dan oleh karena itu supaya destinasi pariwisata dapat dipilih oleh mayoritas para pengunjung, maka destinasi harus dapat memenangkan persaingan tersebut. Salah satu cara untuk memenangkan persaingan adalah dengan melakukan strategi bersaing destinasi pariwisata yang tujuannya agar unggul dalam lingkungan persaingan. Berdasarkan hal tersebut, terdapat urgensi untuk dilakukannya penelitian tentang upaya penguatan sektor pariwisata terutama berkaitan dengan peran penting masyarakat lokal. Fokus penelitian ini ditujukan untuk menjawab pertanyaan tentang: "Bagaimana upaya Agrowisata Kebun Blimbing Ngringinrejo Bojonegoro untuk dapat bersaing satu sama lain dalam rangka menarik lebih banyak pengunjung yang melakukan perjalanan ke Agrowisata Kebun Blimbing Ngringinrejo Bojonegoro setiap tahun dan mempengaruhinya menjadi pelanggan atau wisatawan tetap di tempat tujuan tersebut?". Dari sini tujuan penelitian antara lain untuk menjelaskan dan menganalisis model keunggulan bersaing Agrowisata Kebun Belimbing Ngringinrejo serta rumusan strategi generik yang sesuai bagi Agrowisata Kebun Belimbing Ngringinrejo tersebut.

\section{KAJIAN TEORI}

Strategi secara umum mampu mendorong terbentuknya model yang koheren untuk semua unit bisnis dan memastikan bahwa semua pihak yang terlibat dalam perencanaan strategis dan implementasinya mengikuti tujuan bersama (Porter, 1997). Hill dan Jones (2009) menyatakan bahwa "sebuah perusahaan memiliki persaingan keuntungan atas para pesaingnya ketika profitabilitasnya lebih besar dari rata-rata profitabilitas semua perusahaan dalam industrinya". Tentunya tidak ada keunggulan kompetitif akan bersifat permanen karena suatu perusahaan dapat memperoleh keterampilan yang dibutuhkan untuk menduplikasi manfaat dari strategi penciptaan nilai perusahaan (Lei dan Slocum, 2005). Dengan demikian, keunggulan kompetitif berkelanjutan terjadi ketika perusahaan mampu mempertahankan profitabilitas di atas rata-rata di atas sejumlah tahun (Hill dan Jones, 2009).

Model permintaan-pariwisata telah diadaptasi dalam literatur sebagai kerangka model yang tepat dalam memperkirakan wisatawan, baik domestik maupun internasional (Lim, 1997; Morley, 1998; Sinclair, 1998). Variabel dalam model ini termasuk arus pariwisata yang diukur dengan jumlah kedatangan dan keberangkatan, atau berdasarkan permintaan dalam hal pengeluaran dan tanda terima. Aliran penerimaan mungkin sedikit lebih unggul dari variabel lainnya karena secara tidak langsung menyertakan dimensi jumlah hari yang dihabiskan oleh wisatawan pada tujuan individu. 


\section{Competitive Strategy dalam Pariwisata}

Pada dasarnya manajemen strategi dan pariwisata adalah bidang studi yang relatif muda, tetapi pada kedua konsep tersebut telah dikembangkan literatur luas yang disatukan. Salah satu pertanyaan mendasar dalam bidang manajemen strategis adalah bagaimana memastikan dan mempertahankan keuntungan kompetitif. Rencana bisnis strategis yang komprehensif (yaitu, rencana pengembangan dan promosi) perlu dirumuskan untuk mengatasi lebih banyak masalah yang berdampak pada kualitas produk pariwisata, termasuk: kepadatan penduduk, masalah lingkungan, keselamatan dan keamanan pengunjung, masalah musiman, dan kepekaan terhadap budaya lokal. Konsep perencanaan mungkin tidak baru bagi manajer pariwisata di sektor publik dan swasta. Namun, mengembangkan dan mengimplementasikan rencana strategis yang menghasilkan hasil dalam industri yang kompetitif merupakan persyaratan penting jika suatu entitas bisnis berharap untuk berhasil di masa depan.

Pendekatan semacam ini didasarkan pada premis bahwa pencapaian keunggulan kompetitif yang berkelanjutan cenderung bervariasi dalam situasi yang berbeda. Perbedaan antara industri serta perusahaan individu dalam industri, kemungkinan akan berdampak pada bagaimana keunggulan kompetitif, yang dipertahankan selama periode waktu, dan difasilitasi. Sehingga, pencapaian atas hal tersebut menjadi sebuah konteks spesifik, kemudian karakteristik khusus dari industri tetap harus dipertimbangkan. Konsep wisata ini memiliki sejumlah karakteristik penentu yang perlu dipertimbangkan dalam memahami bagaimana keunggulan kompetitif berkelanjutan dapat tercapai.

Sebagai contoh organisasi perhotelan dapat berhasil memposisikan diri di industri hotel dengan memanfaatkan keunggulan kompetitifnya (Christou dan Karamanidis, 1999). Tampaknya cukup menantang untuk menyelidiki nilai praktis seperti Teori Porter dalam lingkungan yang berubah dengan cepat pada awal milenium ketiga. Hasilnya dapat digunakan sebagai rangsangan untuk penelitian yang lebih rinci, berfokus pada masalah perencanaan strategis dalam kaitannya dengan daya saing.

Secara umum strategi kompetitif adalah "pencarian posisi kompetitif yang menguntungkan di industri. Ini bertujuan untuk membangun posisi yang menguntungkan dan berkelanjutan melawan kekuatan yang menentukan persaingan industri "(Porter, 1985). Pencarian kekuatan dan faktor yang menentukan daya saing industri pariwisata adalah wilayah yang belum sepenuhnya dieksplorasi (Dwyer, et al. 2003). Dalam konteks pariwisata, konsep daya saing telah diterapkan pada setting yang berbeda. Berbagai penulis telah menghubungkan daya saing dengan perspektif ekonomi, pemasaran dan strategis, harga, kualitas dan kepuasan. Dwyer dan Kim (2003) menjelaskan untuk mencapai keunggulan kompetitif bagi industri pariwisata, tujuan apapun harus memastikan bahwa keseluruhan 'daya tarik', dan pengalaman wisata yang ditawarkan, harus lebih unggul daripada tujuan alternatif yang terbuka bagi calon pengunjung. Kunjungan yang ada dan potensial ke tujuan manapun sangat terkait dengan daya saing keseluruhan tujuan itu, namun hal itu didefinisikan atau diukur. 
Poon (1993) mengemukakan empat prinsip utama yang harus diikuti oleh tujuan jika harus bersaing: menempatkan lingkungan lebih dulu; menjadikan pariwisata sebagai sektor unggulan; memperkuat jalur distribusi di pasar, dan membangun sektor swasta yang dinamis. Sebuah tujuan dapat dikatakan kompetitif jika pangsa pasarnya, yang diukur dengan jumlah pengunjung dan keuntungan finansial meningkat (Hassan, 2000). Pendekatan ini mendukung pandangan luas bahwa daya saing harus dikaitkan dengan tujuan jumlah pengunjung yang tinggi dan peningkatan pendapatan.

Daya saing di sektor pariwisata adalah kapasitas usaha pariwisata untuk menarik pengunjung asing maupun domestik yang berkunjung pada daerah tujuan wisata tertentu. Peningkatan daya saing dapat dicapai dengan memanfaatkan sumberdaya yang ada, meningkatkan kapabilitas pengelolaan sehingga mempunyai daya saing. Akibatnya apabila ada peningkatan daya saing daerah tujuan wisata, akan menjadikan daerah tujuan wisata lebih menarik, sehingga bisa meningkatkan jumlah kunjungan wisatawan. Jadi daya saing daerah tujuan wisata merupakan kemampuan suatu daerah untuk meningkatkan pendapatan asli daerah dari sektor wisata, pengembangan daerah dan membuka kesempatan kerja, dibandingkan dengan daerah lainnya yang saling berdekatan.

\section{Kerangka Konseptual Penelitian}

Pengembangan pariwisata adalah suatu usaha untuk mengembangkan atau memajukan objek wisata menjadi lebih baik dan lebih menarik ditinjau dari segi tempat maupun benda-benda yang ada didalamnya untuk dapat menarik minat wisatawan untuk mengunjunginya. Pengembangan kepariwisataan pada suatu daerah tujuan wisata akan selalu diperhitungkan dengan keuntungan dan manfaat bagi masyarakat banyak. Dalam kerangka pemikiran ini akan dijelaskan mengenai alur berfikir yang digunakan dalam penelitian ini. Kerangka konseptual penelitian ini didasarkan pada model diamond porter dalam analisis keunggulan bersaing di sektor agriculture, dengan mengacu pada hasil kajian oleh Karacsony (2008); Al-Hiary, et al. (2010); Sterns dan Spreen (2010); Dlamini, et al. (2014). Faktor-faktor penentu atau determinan keunggulan bersaing yang digunakan dalam studi ini meliputi: kondisi faktor (factor conditions), kondisi permintaan (demand conditions), related and supporting industries, firm strategy, structure and rivalry, pemerintah, dan peluang (chance). Dari determinan tersebut, kemudian dirumuskan beberapa implikasi keunggulan berkelanjutan untuk sektor agrowisata kebun blimbing Ngringinrejo, serta strategi generik yang sesuai dalam pengembangan agrowisata tersebut.

Menurut Porter (1998), kerangka lengkap yang ia sebut 'diamond' merupakan sistem dinamis di mana semua elemen berinteraksi dan saling menguatkan. Penelitian ini menggunakan 'diamond' dan mencoba untuk melihat bagaimana setiap fungsi penentu dan berinteraksi dengan faktor penentu lain dalam sektor agrowisata kebun blimbing Ngringinrejo dengan menganalisis determinannya. Kerangka konseptual yang dibangun dalam penelitian ini ditunjukkan pada Gambar 1. 


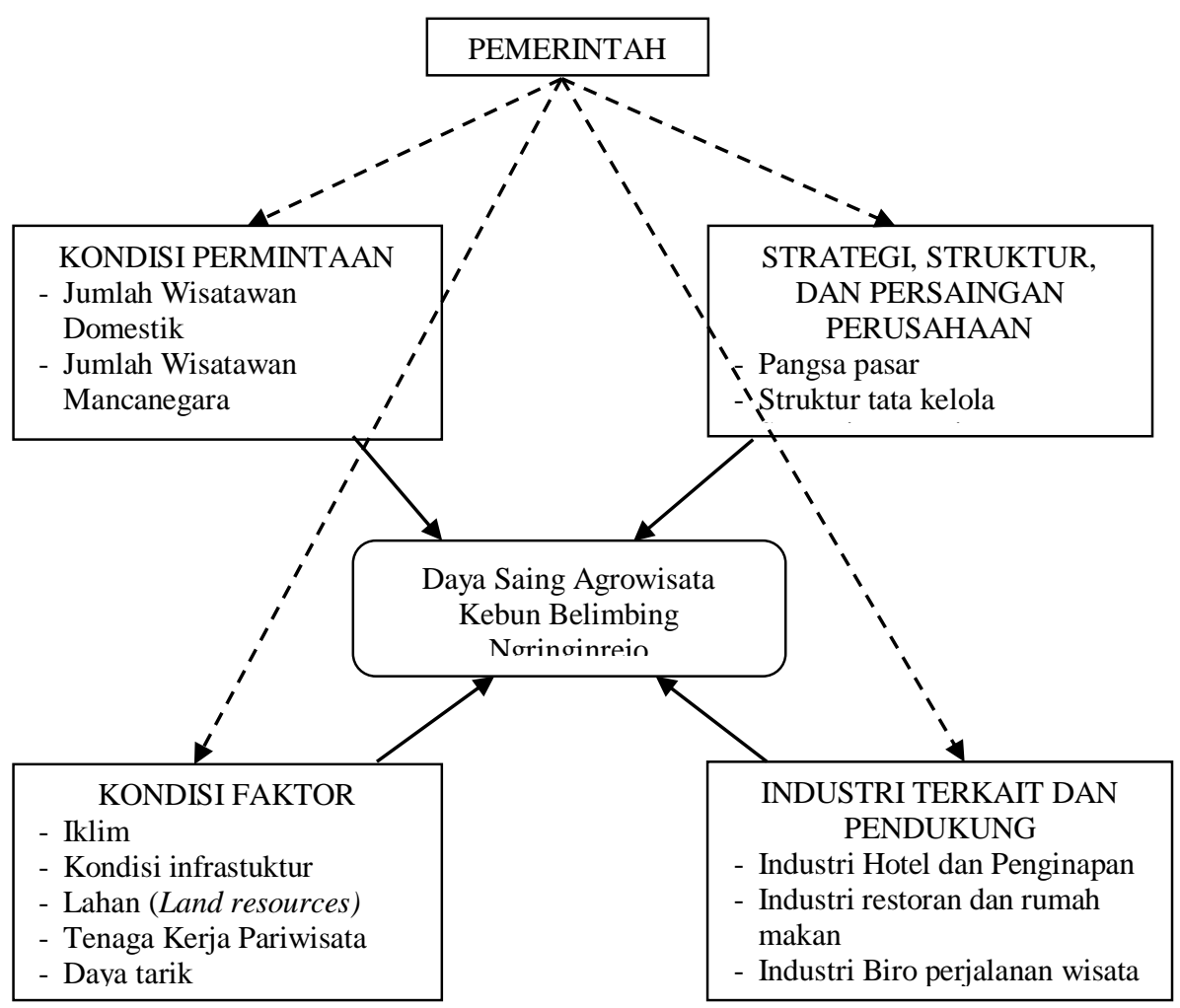

\section{Metodologi Penelitian}

Penelitian ini menggunakan pendekatan penelitian secara kualitatif, dengan lokasi pada kawasan agrowisata kebun belimbing Ngringinrejo, Bojonegoro Jawa Timur. Informan yang dipillih merupakan para pengelola atau karyawan agrowisata kebun belimbing Ngringinrejo dan masyarakat sekitar kawasan agrowisata tersebut. Pengumpulan data dalam penelitian ini dilakukan dengan menggunakan teknik wawancara, observasi, dan dokumentasi. Sementara analisis data penelitian menggunakan pendekatan fenomenologi yang dikembangkan oleh Creswell (2010).

\section{HASIL ANALISIS DATA DAN PEMBAHASAN}

\section{A. Model Keunggulan Bersaing Agrowisata Kebun Belimbing Ngringinrejo}

Kinerja daya saing merupakan kemampuan suatu industri atau perusahaan atau sektor dalam menarik investasi dan sumber daya langka lainnya dengan menjual produk pada pasar global, selain berupaya untuk mendapatkan opportunity cost dari sumber daya. Tentunya keunggulan kompetitif atau daya saing merupakan upaya mencapai kemakmuran melalui pilihan strategis. Dengan upaya maksimal agar Agrowisata Kebun Blimbing Ngringinrejo dapat bersaing secara efektif di pasar persaingan pariwisata, bagaimanapun produk harus dapat diproduksi secara kompetitif.

\section{competitive advantages)}


Porter (2010) melalui konsep Porter's Diamond menyatakan bahwa "keunggulan kompetitif diciptakan dan dipertahankan melalui proses yang sangat lokal." Selain itu, Porter juga menjelaskan bahwa perbedaan dalam struktur, nilai, budaya dan lembaga ekonomi suatu negara atau kawasan mempengaruhi daya saingnya bersama dengan gagasan tradisional tentang sumber daya dan harga faktor. Dalam obyek agrowisata kebun belimbing Ngringinrejo, paparan ini merupakan konsekuensi tak terelakkan dari sifat biologis produksi tanaman, khususnya belimbing, yang tentunya bertalian erat dengan kemungkinan terjadinya bencana, seperti cuaca buruk, wabah penyakit, dan infestasi hama. Hal inilah yang kemudian memunculkan pertanyaan, "Di pasar pertanian dan pangan, baik dalam skala nasional maupun regional, apakah keunggulan kompetitif jangka panjang dari berbagai fungsi industri pertanian (agriculture) tidak hanya bergantung pada kapasitas masing-masing industri untuk meningkatkan, berinovasi dan tumbuh, tetapi juga fungsi dari kapasitasnya untuk merespon krisis?".

Berikut ini merupakan informasi hasil observasi lapangan pada agrowisata kebun belimbing Ngringinrejo, yang dipaparkan berdasarkan beberapa determinan sesuai kerangka konseptual penelitian yang ditentukan sebelumnya.

\section{Kondisi Faktor (Factor Conditions)}

Kondisi faktor merupakan faktor-faktor "kunci" produksi (atau faktor-faktor khusus) yang diciptakan. Faktor-faktor khusus produksi yang dinilai paling penting dalam mempengaruhi objek agrowisata kebun blimbing Ngringinrejo meliputi adalah iklim, kondisi infrastuktur, lahan (land resources), tenaga kerja, dan daya tarik agrowisata.

a. Iklim

Secara umum, Wilayah Kabupaten Bojonegoro memiliki iklim tropis, dengan suhu udara berkisar antara 24,2 C - 31,4 C. Karena beriklim tropis sehingga wilayah ini hanya mengenal dua musim, yakni musim kemarau dan musim hujan. Berdasarkan kondisi topografi yang berada di ketinggian 0 sampai kurang dari 1000 meter di atas permukaan air laut, menyebabkan curah hujan di daerah ini akan dapat mempengaruhi baik secara langsung maupun tidak langsung langsung pada jenis dan pola tanam serta tersedianya air sebagai sumber pengairan (hidrologi).

Daerah Ngringinrejo merupakan kelompok daerah dataran rendah yang rawan terhadap bencana banjir. Dengan kondisi tanah yang cenderung basah dan berlumpur, menyebabkan daerah ini mengalami hambatan dalam bidang pertanian. Tidak semua tanaman dapat tumbuh subur di Desa Ngringinrejo, terutama buah-buahan, sehingga salah satu tanaman yang saat ini dinilai sesuai dan cocok, baik dengan kondisi iklim maupun tanahnya adalah pohon belimbing. Dengan tingginya pertumbuhan produksi belimbing di daerah ini, menjadikan Desa Ngringinrejo sebagai salah satu kawasan holtikultura untuk sentra produk belimbing di Kabupaten Bojonegoro. Hal inilah yang melatar belakangi pendirian agrowisata kebun belimbing di Desa Ngringinrejo Kecamatan Kalitidu tersebut. 
b. Kondisi Infrastruktur

Kondisi infrastruktur dalam konteks kajian ini dijelaskan melalui tingkat aksesibilitas kawasan agrowisata kebun belimbing Ngringinrejo. Berdasarkan data yang diperoleh dari pihak manajemen Agrowisata, bahwa kondisi infrastruktur terkait kualitas jalan di dalam Desa sudah dalam keadaan berpaving, dengan ketersediaan petunjuk arah yang cukup. Jarak antara lokasi agrowisata dengan Kota Kabupaten Bojonegoro kurang lebih membutuhkan waktu tempuh 30 menit, sementara dari Kota Propinsi membutuhkan waktu tempuh kurang lebih tiga jam. Alat transportasi yang bisa digunakan untuk menjangkau lokasi agrowisata adalah sepeda, motor, atau mobil. Terdapat pula ojek dan kereta kelinci di area wisata sehingga memudahkan para wisatawan dalam mengakses jalan di area sekitar lokasi.

Selain itu, pihak manajemen telah menyediakan 53 lapak penjual buah belimbing dan produk olahan belimbing, beberapa warung kopi di dalam kebun, tujuh stand warung makan, beberapa kamar mandi dan WC yang memadai, mushola, air bersih, listrik, tempat parkir, tempat sampah, toko cinderamata, jaringan telepon selular dengan kualitas signal yang kuat dan dilengkapi dengan wifi, dua pendapa untuk rapat dan berkumpul, satu ruang rapat eksklusif ber AC, ruang karaoke terbuka, dan 17 gazebo. Untuk fasilitas panggung hiburan masih belum tersedia saat ini, sementara ketersediaan Bank dan money changer serta kantor pos masih cukup jauh.

c. Lahan

Luas Wilayah Desa Ngringinrejo keseluruhan adalah kurang lebih 166,065 Ha. Dari luas tersebut, sekitar 48.36 persen digunakan sebagai lahan sawah dan 23.78 persen digunakan sebagai lahan perkebunan rakyat. Untuk kebutuhan agrowisata belimbing sendiri, sebanyak kurang lebih 20.5 Ha digunakan sebagai kebun belimbing. Saat ini, jumlah tanaman belimbing diperkirakan sebanyak 10.250 pohon, dengan masa panen sekitar tiga bulan (atau empat kali per tahun) dan kapasitas produksi sebesar kurang lebih 80 kg/pohon setiap tahunnya.

Untuk dapat menghasilkan buah belimbing yang berkualitas, perlu dilakukan penanganan intensif terhadap lahan kebun belimbing, mulai dari pemeliharaan tanah, perawatan pohon, hingga proses pemanenan dan pasca panen. Beberapa langkah yang dilakukan oleh para petani belimbing di kawasan agrowisata antara lain pendangiran/pencangkulan, pemupukan, pengairan, pengendalian hama OPT, pemblongsongan buah, pemangkasan cabang, dan peremajaan pohon.

d. Tenaga Kerja

Agrowisata kebun belimbing Ngringinrejo merupakan salah satu sektor pariwisata berbasis pertanian padat karya yang dapat menyediakan lapangan kerja dipedesaan. Dengan dibentuknya 
agrowisata ini tentunya banyak menyerap tenaga kerja, mulai dari tenaga kerja untuk budidaya tanaman, perawatan tanaman, hingga pengelolaan dan pemasaran. Jumlah warga Desa Ngringinrejo yang terlibat secara langsung dalam pengelolaan Agrowisata Belimbing adalah sebanyak 9.4 persen, dimana 52 persen diantaranya berperan sebagai pemilik lahan, 19 persen sebagai pembudidaya belimbing, dan 18 persen sebagai penjual belimbing. Pengelolaan Agrowisata belimbing ini ditangani oleh Pokdarwis (Kelompok Sadar Wisata) Desa Canggu, dengan struktur lembaga pengelola bernama Pokdarwis Agro Jaya. Sementara untuk ketersediaan pemandu wisata, saat ini terdapat dua orang tenaga pemandu.

e. Daya Tarik

Daya tarik yang dimiliki oleh agrowisata kebun belimbing Ngringinrejo terdiri atas daya tarik alam, daya tarik budaya, dan daya tarik buatan. Daya tarik alam yang dimiliki berupa agrowisata belimbing itu sendiri, kemudian bendungan gerak, area outbond, bumi perkemahan, dan wisata banjir. Sementara daya tarik budaya yang dimiliki antara lain festival belimbing sebagai daya tarik utama, serta seni reog, seni rebana, dan hadrah sebagai daya tarik pendukung. Selain dua daya tarik di atas (daya tarik alam dan daya tarik budaya) yang merupakan hasil dari pengolahan dan pemberdayaan sumber daya asli daerah, terdapat pula daya tarik buatan yang merupakan hasil dari pemberdayaan ketrampilan dan keahlian masyarakat. Daya tarik buatan tersebut dapat dilihat dari kerajinan anyaman sebagai daya tarik utama, serta Usaha Kecil dan Menengah (UKM), kuliner khas daerah, dan pembudidayaan ikan air tawar sebagai daya tarik pendukung.

\section{Kondisi Permintaan (Demand Conditions)}

Kondisi permintaan memungkinkan semakin tingginya tuntutan pelanggan dalam ekonomi, sehingga menyebabkan semakin besarnya tekanan yang dihadapi perusahaan untuk terus meningkatkan daya saing mereka melalui produk inovatif dan kualitas tinggi. Hasil penelitian mengkonfirmasi hipotesis Porter (1990), bahwasanya dengan semakin berkembangnya Kota Bojonegoro secara perekonomian, hal ini berdampak pada semakin diperhitungkannya Kota Bojonegoro beserta Daerah-daerah yang ada di Kawasan tersebut oleh masyarakat luas. Hal ini berarti bahwa produk pertanian menghadapi potensi peningkatan permintaan yang besar.

Kondisi permintaan dalam kajian ini dijelaskan dalam dua komponen utama, yakni jumlah kunjungan wisatawan agrowisata belimbing (baik wisatawan nusantara/lokal maupun wisatawan mancanegara) dan jumlah permintaan pasokan terhadap hasil produksi agrowisata belimbing.

a. Jumlah Kunjungan Wisatawan

Berdasarkan data kunjungan agrowisata belimbing Ngringinrejo yang diterbitkan oleh pihak pengelola agrowisata, diketahui bahwa dalam tiga tahun terakhir persentase kunjungan 
mengalami peningkatan cukup signifikan. Pada tahun 2015 jumlah kunjungan diketahui sebanyak 111.028 orang wisatawan, kemudian pada tahun 2016 jumlah tersebut meningkat menjadi 137.824 orang wisatawan, dan pada tahun 2017 jumlah wisatawan meningkat lagi menjadi 145.712 orang. Dari jumlah di atas, sebagian besar merupakan wisatawan lokal, sementara penyerapan wisatawan mancanegara hanya sekitar 12 orang per tahun.

Peningkatan terhadap jumlah kunjungan wisatawan mengindikasikan semakin meningkatnya permintaan atas kebutuhan wisata, baik dari aspek experience maupun produk agrowisata. Dapat dilihat pula, bahwa agrowisata belimbing ini dapat memenuhi preferensi wisatawan dalam mencapai tujuan berwisata. Beberapa kegiatan perekonomian masyarakat selain paket wisata agro, yang secara tidak langsung juga dapat mendorong peningkatan daya tarik wisatawan untuk datang ke agrowisata belimbing adalah kegiatan kesenian, kuliner, wisata air, dan kerajinan.

Dengan meningkatkan jumlah kunjungan wisatawan secara otomatis dapat meningkatkan pendapatan operasional agrowisata belimbing ini. Dari data laporan dipublikasikan oleh agrowisata belimbing selama tiga tahun terakhir diketahui bahwa pendapatan tiket masuk pada tahun 2015 adalah sebesar Rp. 113.845.000, kemudian pada tahun 2016 sebesar Rp. 217.663.000, dan pada tahun 2017 sebesar Rp. 291.594.000. Dari kenaikan pendapatan tiket masuk yang cukup signifikan tersebut, tidak serta merta meningkatkan biaya cetak tiketnya. Hal ini dapat dilihat dari total biaya cetak tiket yang secara berturut-turut mengalami penurunan selama tiga tahun terakhir, yakni sebesar Rp. 8.920.000 pada tahun 2015, kemudian menurun menjadi Rp. 7.650.000 pada tahun 2016, dan menurun lagi menjadi Rp. 4.917.000 pada tahun 2017. Kondisi di atas mengindikasikan bahwa tingkat profibalitas agrowisata cukup tinggi, sehingga sangat memungkinkan untuk semakin meningkatkan kesejahteraan para stakeholder agrowisata belimbing. Dengan pengelolaan, inovasi, dan pengembangan yang semakin baik, maka prospek agrowisata belimbing akan semakin baik ke depannya.

b. Jumlah permintaan pasokan produk

Selain dari jumlah kunjungan wisatawan, kondisi permintaan juga dapat dilihat dari besarnya jumlah permintaan terhadap produk agrowisata belimbing. Secara ekonomi, dari total luas lahan sebesar kurang lebih $20.5 \mathrm{Ha}, 104$ orang petani, dan 10.250 pohon belimbing, kebun belimbing Ngringinrejo diperkirakan dapat memproduksi sekitar $855.000 \mathrm{~kg}$ buah belimbing setiap tahunnya. Estimasi perputaran uang dari hasil penjualan belimbing diperkirakan mencapai kurang lebih tiga milyar per tahun. Dari jumlah tersebut, masih berpotensi untuk terus meningkat lagi sejalan dengan semakin inovatifnya masyakat dalam mengolah produk belimbing tersebut. Saat ini produk hasil olahan belimbing yang diproduksi oleh masyarakat antara lain sirup belimbing, sari buah belimbing, dan dodol belimbing. 
Meningkatkan permintaan terhadap produk agrowisata belimbing ini adalah karena secara kualitas, belimbing yang dihasilkan oleh kebun agrowisata belimbing Ngringinrejo ini memang jauh lebih baik dibandingan dengan belimbing dari daerah lain. Selain itu, terdapat beberapa varietas yang dihasilkan oleh petani belimbing, diantaranya varietas bangkok merah, varietas blitar, varietas demak, dan varietas lokal.

Salah satu kerjasama yang berhasil dibangun dalam penyediaan pasokan buah belimbing dan produk olahan belimbing adalah dengan PT. Carrefour. Pihak Carrefour telah menyetujui kontrak permintaan supply buah belimbing dari agrowisata sebanyak satu ton setiap minggunya. Selain itu, Carrefour juga bersedia untuk memasarkan produk hasil olahan belimbing yang diproduksi oleh agrowisata belimbing Ngringinrejo tersebut. Tentunya hal ini menjadi tantangan tersendiri bagi para petani, karena selain berusaha menjaga kualitas hasil panennya, para petani juga harus berusaha meminimalisir risiko gagal panen pada setiap tanaman belimbingnya.

\section{Struktur, Strategi, dan Persaingan Perusahaan (Firm Structure, Strategy, and Rivalry)}

Porter (1990) mengidentifikasi persaingan sebagai penggerak paling penting dari keunggulan kompetitif perusahaan-perusahaan suatu negara. Porter percaya bahwa persaingan dalam negeri memaksa perusahaan untuk bersaing dalam hal efisiensi biaya, peningkatkan kualitas dan melakukan inovasi. Dalam konteks strategi, struktur, dan persaingan perusahaan, pemaparan hasil pada kajian agrowisata kebun belimbing Ngringinrejo lebih dispesifikasikan pada pangsa pasar, struktur tata kelola, dan strategi promosi agrowisata.

a. Pangsa pasar

Fungsi dasar sebuah pasar adalah menyediakan tempat pasar bagi produsen, pengecer dan agen komisi untuk melakukan transaksi jual dan beli. Dengan pengecualian yang sangat terbatas, pemasaran produk belimbing di kawasan agrowisata belimbing Desa Ngringinrejo selalu menjadi perhatian banyak pihak, tidak terkecuali sektor swasta. Saluran pemasaran yang berlaku tidak hanya menggunakan sistem penjualan langsung (dari petani atau pedagang ke konsumen), namun juga melibatkan pergerakan produk ke salah satu pasar grosir.

Pangsa pasar produk belimbing di kawasan agrowisata kebun belimbing Ngringinrejo ini meliputi pasar lokal, regional, dan internasional. Peningkatan pada grafik kunjungan wisatawan menunjukkan bahwa pangsa pasar agrowisata belimbing ini juga semakin luas. Dari hasil penjualan produk belimbing, para pedagang bisa memperoleh pendapatan yang berlipat di hari libur, bahkan pendapatan dikalkulasi bisa mencapai Rp 5.000.000 hingga Rp 6.000.000 di hari-hari tertentu. Sistem penjualan produk yang digunakan adalah penjualan langsung (direct selling) di lapak-lapak kebun atau stand pedagang di area agrowisata serta penjualan tidak langsung (indirect selling) melalui perantara/tengkulak luar kota yang 
sudah menjadi pelanggan tetap. Seringkali pula para wisatawan datang langsung untuk memesan produk pertanian dalam jumlah yang banyak, yang umumnya bertujuan untuk diperjualbelikan kembali di daerah asal wisatawan tersebut.

b. Struktur tata kelola

Pengelolaan agrowisata kebun belimbing Ngringinrejo di jalankan oleh Kelompok Sadar Wisata (Pokdarwis), yang beranggotakan para masyarakat setempat dalam wadah koperasi yang bernama "Pokdarwis Agro Jaya". Visi Pokdarwis itu sendiri adalah untuk meningkatkan kesejahteraan ekonomi masyarakat dan mensukseskan pembangunan Desa melalui agrowisata. Sementara misinya adalah untuk:

- Meningkatkan peran serta masyarakat dalam menumbuhkembangkan agrowisata.

- Membangun, menumbuhkan, dan mewujudkan sapta pesona.

- Menggali potensi dan daya tarik yang ada di Desa, baik melalui sumber daya alam maupun budaya.

Sistem pengelolaan agrowisata belimbing juga dilakukan secara terintegrasi, dengan melibatkan beberapa dinas terkait seperti dinas pertanian, dinas pariwisata, dinas pekerjaan umum, serta dinas perdagangan dan perindustrian. Untuk pengembangan usaha agrowisata, pihak pengelola telah menetapkan program pelatihan, seperti pelatihan guide, pelatihan pengurus pokdarwis, pelatihan teknologi informasi dan teknologi, dan lain-lain. Selain itu, berbagai upaya penguatan juga telah dilakukan, seperti integrasi sekolah lapang, baik sekolah lapang pengendalian hama terpadu (SLPHT) maupun sekolah lapang good agriculture practice, guna membekali masyarakat dalam budidaya tanaman belimbing.

c. Strategi promosi

Promosi sebagai bagian dari fungsi pemasaran merupakan salah satu faktor penting yang harus pertimbangkan oleh manajemen agrowisata belimbing Ngringinrejo dalam upaya mengdongkrak pendapatan, memperluas market share dan mempertahankan sustainability usaha. Dari sini, pihak manajemen atau pengelola, melalui pendampingan dari pemerintah (baik pemerintah Desa maupun pemerintah Kabupaten) telah melakukan berbagai strategi promosi dan pencitraan.

Berbagai upaya strategi promosi telah dilakukan, baik melalui web Kota Bojonegoro, media cetak, media sosial, maupun eventevent. Salah satu event yang paling besar adalah festival belimbing 2014. Festival perdana yang diselenggarakan oleh pengelola dan pengurus agrowisata belimbing tersebut dihadiri oleh ratusan masyarakat pengunjung, baik dari daerah setempat maupun dari luar daerah. Selain itu, dilihat dari laporan keuangan yang dipublikasikan oleh agrowisata belimbing selama tiga tahun terakhir, menunjukkan bahwa biaya yang dikeluarkan untuk promosi dan pencitraan agrowisata cukup besar. Bahkan pengeluaran untuk promosi dan pencitraan ini terus meningkat setiap tahunnya, yakni sebesar Rp. 
27.684.000 di tahun 2015, kemudian meningkat menjadi Rp. 58.094.000 di tahun 2016, dan meningkat lagi menjadi Rp. 74.923.000 di tahun 2017. Terlebih lagi, dengan terpilihnya Agrowisata belimbing Ngringinrejo sebagai wisata buatan se-Jawa Timur pada ajang perhargaan tahun 2015 lalu, telah memberikan nilai tambah dan ketertarikan masyarakat untuk berkunjung di kawasan agrowisata belimbing ini.

\section{Industri Terkait dan Pendukung (Related and Supporting Industries)}

Ketersediaan industri terkait dan pendukung dapat memberikan dukungan tersendiri bagi agrowisata kebun belimbing Ngringinrejo. Hal ini memungkinkan dalam memfasilitasi pertukaran informasi dan mendorong pertukaran ide dan inovasi secara berkelanjutan. Dalam kajian studi ini, industri terkait dan pendukung bagi agrowisata kebun belimbing diantaranya industri hotel, industri restoran dan rumah makan, serta industri biro perjalanan wisata (tour and travel).

a. Industri Hotel dan Penginapan

Berdasarkan data Dinas Pariwisata dan Kebudayaan Bojonegoro pada tahun 2016, terdapat 18 hotel di Kota Bojonegoro, diantaranya adalah Hotel MCM, Hotel Griya Dharma Kusuma, Hotel Aston, Hotel Fave, Hotel Bojonegoro, Hotel Kudus, Hotel Wina, Hotel Pazia, Hotel Panatau Sukses, Hotel Dewarna, Hotel Wisma Jaya, Alciro Home Stay, Hotel Grand Olimpic, Hotel Nirwana, Hotel Bonero, Hotel Layung, Hotel Djoglo Kalitidu, Hotel Sinar Bintang.

Dengan keberadaan hotel sebagai sarana akomodasi di sekitar area agrowisata, baik itu di Kecamatan Kalitidu maupun Kabupaten Bojonegoro (membutuhkan jarak tempuh 30 menit), akan memudahkan para wisatawan untuk menikmati waktu liburan mereka dengan lebih menyenangkan dan memuaskan.

b. Industri Restoran dan Rumah Makan

Industri restoran dan rumah makan memungkinkan para wisatawan untuk tidak hanya menikmasi berwisata di agrowisata kebun belimbing Ngringinrejo, tapi juga memberikan kesempatan bagi wisatawan untuk mengeksplore kuliner yang ada di daerah Bojonegoro.

Beberapa restoran dan rumah makan di Kawasan Bojonegoro berdasarkan lokasinya terdiri atas: lokasi di Jalan Gajah Mada, antara lain Warung Bu Surip (berlokasi di timur stasiun Bojonegoro), Warung Libra dan warung Ladi (berlokasi di depan stasiun Bojonegoro), Warung Mbak Yanti (berlokasi di barat Stasiun Bojonegoro), Warung Murah Meriah, Warung Indah, dan Warung Jos Raos. Lokasi di Jalan Untung Suropati, antara lain Javanila Resto, Warung Bakri (berada di barat Tugu Adipura), dan Warung Bakri. Lokasi di Jalan Diponegoro, antara lain Rumah makan Kudus dan Asem-asem Gang Jiken. Lokasi di Jalan Panglima Polim, antara lain KQ5 dan Warung Bambu Dahsyat. Lokasi di Jalan Monginsidi, antara lain Omah Pule. Lokasi di Desa Bendo Kapas, antara lain Welut Bendo. Lokasi di Jalan Veteran, 
antara lain Warung Apung Rahmawati dan Damai Resto \& Cafe. Lokasi di Jalan Pemuda, antara lain MCM Hotel \& Resto.

c. Industri Biro Perjalanan Wisata (Tour and Travel)

Berdasarkan data wisata Bojonegoro tahun 2017, bahwasanya terdapat 18 tour \& travel di Kawasan Bojonegoro, yakni Erika Tour \& Travel, Se Tour \& Travel, Tourindo Tour \& Travel, Mitra Tour \& Travel, Warrock Tour \& Travel, Shafira Tour \& Travel, AP Tour \& Travel, Leana Tour \& Travel, Dipa Raja Tour \& Travel, Safara Tour \& Travel, Genta Visi Khayangan Abadi, ExplorAdventure, DF Tour \& Travel, Kantaloka Wisata, Paradiso Tour \& Travel, RN Tour \& Travel, Angling Dharma T\&T, dan Duta Wahana T\&T.

Dengan banyaknya biro perjalanan wisata yang ada di Kota Bojonegoro, memudahkan para wisatawan untuk dapat menjangkau lokasi-lokasi pariwisata di Bojonegoro, khususnya lokasi agrowisata kebun belimbing Ngrininrejo.

\section{Pemerintah (Government)}

Peran pemerintah, baik pemerintah Desa maupun pemerintah Kabupaten Bojonegoro dalam pengembangan kawasan agrowisata kebun belimbing Ngringinrejo adalah sebagai fasilitator dan katalisator. Berdasarkan keputusan Bupati Bojonegoro No. 188/183A/KEP/412.12/2008 tentang penetapan kawasan Agropolitan, pemerintah Kabupaten Bojonegoro telah menetapkan tiga kecamatan sebagai wilayah Agropolitan di Bojonegoro. Wilayah tersebut antara lain Kecamatan Kapas, Kecamatan Dander dan Kecamatan Kalitidu (KADEKA).

Selain berupaya untuk mengembangkan keunggulan lokal, program Agropolitan juga didukung oleh perkembangan teknologi informasi dan komunikasi yang sangat pesat. Peran teknologi informasi tersebut tentunya dapat dirasakan dalam berbagai bidang kegiatan masyarakat, termasuk juga dalam bidang pertanian. Oleh karena itu, Pemerintah Kabupaten Bojonegoro bekerja sama dengan Dinas Kominfo telah membangun jaringan internet dan BLC (Broadband Learning Center) di kawasan sekitar agrowisata kebun belimbing. Bahkan, jaringan free wifi juga akan dipasang di area agrowisata belimbing, selain sebagai sarana promosi juga sebagai upaya meningkatkan daya tarik pengunjung agar semakin betah untuk menghabiskan waktu di lokasi agrowisata ini. Secara khusus, fasilitas internet dan BLC juga ditujukan untuk pembelajaran masyarakat setempat dalam meningkatkan wawasan dan kemampuan diri, terutama dalam pengembangan agrowisata. Pemerintah sebagai fasilitator juga berusaha memberikan pendampingan secara intensif, baik dalam program pelatihan pengelola dan pengurus agrowisata, program edukasi pertanian, program pengembangan SDM, dan lain-lain. Dalam hal ini, Pemerintah Desa juga berperan dalam perencanan pembangunan kolam anak disekitar wahana agrowisata belimbing, melengkapi sarana outbond, dan penyediaan perahu boat bagi para wisatawan yang ingin menyusuri sungai Bengawan Solo. 


\section{$>$ Implikasi pada Keunggulan yang Berkelanjutan (Implications for Sustaining Advantages)}

Berdasarkan perbedaan dari determinan keunggulan kompetitif dalam model diamond porter, kemudian disarankan bahwa industri yang rentan pada kejadian luar biasa seperti bencana, wabah penyakit, dan lainlain untuk dapat melakukan analisis strategi terkait dengan keunggulan yang berkelanjutan. Pemerintah Kabupaten Bojonegoro terlihat cukup baik dalam memposisikan diri terhadap daya saingnya sebagai agrowisata. Hal ini didasarkan pada analisis keunggulan bersaing yang telah disampaikan pada bagian sebelumnya. Hasil analisis tersebut mengarah pada dikotomi utama dalam model keunggulan bersaing Agrowisata Kebun Blimbing Ngringinrejo, yang meliputi empat area utama yakni (1) keterlibatan pemerintah; (2) struktur kepemilikan; (3) pasar yang dimasuki (nasional dan regional); (4) ekpansi dari area yang tidak terkendali.

\section{Keterlibatan Pemerintah}

Keterlibatan pemerintah menandai salah satu perbedaan terbesar antara industri pariwisata di satu daerah dengan daerah lainnya dan khususnya Agrowisata Kebun Blimbing Ngringinrejo yang masuk dalam lingkup Pemerintahan Bojonegoro. Dari pengawasan transaksi penanam hingga pendanaan penelitian dan pengembangan, pemerintah Bojonegoro hampir tidak terlibat di bidang tanaman blimbing. Oleh karena itu, sumber daya pemerintah tidak tersedia untuk mendanai penelitian baru dalam upaya memahami biologi penyakit baru tanaman dan mengembangkan taktik untuk mengimbangi dampaknya pada produksi blimbing. Sangat mungkin bahwa solusi jangka panjang untuk blimbing dan penghijauan blimbing dalam bentuk varietas tahan penyakit, pestisida untuk menyerang vektor yang menyebarkan penghijauan dan strategi manajemen lainnya akan dikembangkan di Bojonegoro. Petani Blimbing akan memiliki akses pertama ke penemuan-penemuan ini. Dapat disimpulkan bahwa jaringan kolaboratif perlu dibentuk antara industri agrowisata blimbing dan pemerintah daerah serta dinas pertanian, sehingga mempunyai efek yang sangat positif pada kemampuan agrowisata blimbing dalam mempertahankan keunggulan kompetitifnya di pasar blimbing olahan secara nasional dan bahkan internasional. Lebih dari itu, keterlibatan pemerintah diharapkan tidak sebatas pada fungsinya sebagai fasilitator dan katalisator, namun juga dalam subsidi modal serta investasi mesin dan peralatan yang dibutuhkan dalam proses pengembangan kualitas produk dan pengembangan sarana agrowisata.

\section{Struktur Kepemilikan}

Salah satu perbedaan utama pada struktur kepemilikan di Agrowisata Kebun Blimbing Ngringinrejo adalah tentang derajat dari integrasi vertikal. Kebun Blimbing Ngringinrejo dimiliki oleh masyarakat, yang berarti produksi dan pengolahan Blimbing dilakukan oleh petani lokal (masyarkaat Ngringinrejo), tetapi pengelolaan Kebun secara keseluruhan dilakukan oleh Pokdarwis (Kelompok Sadar Wisata) yang 
dibentuk oleh sekelompok masyarakat tersebut untuk menunjang intensifikasi produk blimbing.

Porter berpendapat bahwa di suatu negara-negara yang cenderung berhasil dalam industri, di mana praktik dan model manajemen organisasi yang disukai oleh wilayah tertentu sangat cocok untuk sumber keunggulan kompetitif industri. Agrowisata blimbing Ngringinrejo Bojonegoro sangat terintegrasi secara vertikal, dengan semua pengolah besar berada di antara petani terbesar. Petani besar lainnya di Bojonegoro dengan cadangan modal yang mencukupi kemungkinan juga akan bertahan ketika strategi manajemen baru berevolusi yang berhubungan langsung dengan ancaman penyakit. Kelompok yang berisiko, bagaimanapun, adalah petani kecil (kurang dari dua hektar) yang kemungkinan mewakili sekitar 40 persen dari jumlah belimbing yang diproduksi di Ngringinrejo Bojonegoro. Struktur kepemilikan di Ngringinrejo diketahui lebih tersebar, karena bersifat kepemilikan individu. Sementara pengelolaan area agrowisata di lakukan oleh Pokdarwis melalui bentuk badan usaha koperasi. Keberadaan manajemen pengolahan blimbing yang tersebar luas, dapat meringankan kerugian yang bersifat nyata. Para penanam atau petani dalam ukuran apapun dapat mengakses praktik pengelolaan blimbing karena praktik ini dikembangkan dan diberikan edukasi dalam bentuk pendidikan dan pelatihan secara umum, sehingga manajemen perusahaan akan dapat dengan cepat mengembangkan tingkat keahlian yang tinggi dalam praktik-praktik baru. Kepemilikan Ngringinrejo yang tersebar, keahlian produksi yang tersebar luas, dan industri pendukung terkait produksi memungkinkan akan dapat memberikan fleksibilitas dan kemampuan adaptasi yang dibutuhkan untuk menghadapi setiap tantangan dan ancaman yang muncul.

\section{Pasar yang Dimasuki}

Porter (1990) mengakui bahwa ukuran permintaan domestik dalam industri tertentu mungkin penting bagi keunggulan nasional di mana terdapat skala atau pembelajaran ekonomi yang signifikan, akan tetapi ia menganggap kehadiran dan tuntutan pembeli yang canggih akan lebih penting lagi. Ketika industri berkembang, konsumen domestik menuntut beragam kebutuhan yang lebih tinggi, seperti desain, layanan, atau merek bersama dengan harga yang kompetitif. Di wilayah industri agrowisata yang masih kurang berkembang, fungsionalitas dan ketersediaan produk agrowisata mungkin cukup untuk memenuhi kebutuhan konsumen. Seiring kemajuan industri, pembeli domestik menuntut tingkat standar yang lebih tinggi agar sesuai dengan selera mereka serta berbagai item yang dibutuhkan dalam gaya hidup beragam mereka (misalnya waktu, tempat, kesempatan).

Dengan melihat permintaan konsumen yang meningkat dari tahun ke tahun, pasar produk agrowisata Blimbing akan mempunyai prospek yang cerah ke depannya. Dengan ukuran dan kualitas buah belimbing yang lebih baik, serta diversifikasi produk melalui hasil olahan belimbing, 
industri agrowisata memiliki posisi yang lebih baik untuk melayani pasarpasar baru dibandingkan dengan mitranya.

Konsumen yang berasal dari lokal mempunyai karakteristik yang berbeda dengan konsumen dari regional atau bahkan internasional. Dalam perspektif pariwisata, seorang turis bisa sangat menuntut serta sensitif terhadap tampilan obyek destinasi pariwisata yang dilihat. Terdapat tantangan dari industri pariwisata untuk model keunggulan bersaing Agrowisata Kebun Blimbing Ngringinrejo, antara lain adalah: a) untuk mendiversifikasikan diri dengan obyek pariwisata lainnya, standar kualitas yang tinggi harus sesuai dengan selera konsumen. Saat industri memperluas pasar yang lebih beragam, maka hal ini memperluas kemungkinan untuk merefleksikan keragaman konsumen atau turis internasional dalam mengembangkan produk-produk baru; (b) menjadikan merek yang kuat dan luas secara efektif, bersama dengan internasionalisasi merek lokal, industri dapat menggunakan investasi langsung yang berasal dari luar.

\section{Ekspansi dari Area yang Tidak Terkendali}

Menurut Porter (1998), kondisi faktor mengacu pada faktor-faktor produksi yang diperlukan untuk bersaing dalam industri tertentu. Porter juga mengelompokkan faktor pendukung ke dalam sejumlah kategori besar, seperti sumber daya manusia, sumber daya fisik, sumber daya pengetahuan, sumber daya modal dan infrastruktur. Meskipun bukan merupakan topik eksplisit dari kajian studi ini, urban sprawl atau ekspansi dari area yang tidak terkendali memberikan efek yang kuat pada keunggulan kompetitif di Ngringinrejo Bojonegeoro melalui efeknya pada faktor harga. Hal ini dapat dilihat dari peningkatan harga lahan di area sekitar kawasan agrowisata belimbing sebagai dampak dari adanya pengaruh langsung oleh urban sprawl. Fenomena ini juga mempengaruhi biaya tenaga kerja, dengan menarik tenaga kerja dari pasar pertanian ke pasar non-pertanian (misalnya, konstruksi, pertamanan, dan pelayanan makanan). Ada juga tekanan publik yang tinggi untuk meningkatkan upah minimum bagi semua pekerja di Bojonegoro dan untuk memperketat undang-undang ketenagakerjaan. Dengan keinginan nyata Ngringinrejo untuk hidup di kota-kota vertikal dan kebijakan upah rendah terhadap pertanian, jelas bahwa dalam hal harga faktor, Ngringinrejo akan mendapatkan keunggulan kompetitif yang semakin meningkat dalam serangkaian kondisi faktor dasarnya.

\section{B. Rumusan Strategi Generik Agrowisata Kebun Blimbing Ngringinrejo}

Agribisnis telah menunjukkan potensinya untuk mengintegrasikan petani kecil ke dalam sektor dengan berbagai cara inovatif. Pertama, melalui petani yang mengorganisasikan diri menjadi koperasi yang dapat mengambil keuntungan dari skala ekonomi organisasi yang lebih besar, misalnya untuk pembelian input dan penjualan grosir dalam jumlah besar, serta mematuhi standar kualitas. Kedua, dengan menjadi petani kontrak ke perusahaan komersial dengan tanggung jawab untuk memasok komoditas 
pertanian tertentu. Skema ini juga dikenal sebagai 'skema petani luar', memberi kesempatan petani dengan keamanan pasokan dan integritas produk, serta melindunginya dari fluktuasi harga dan permintaan yang ada di pasar terbuka. Penyimpanan dan pengemasan juga dapat menjadi cara untuk membuka potensi sektor pertanian. Melalui pengemasan yang sesuai dan menarik maka dapat meningkatkan value dari produk pertanian tersebut, sehingga harga yang lebih tinggi dapat ditarik untuk kepentingan petani. Sementara penyimpanan dilakukan untuk meningkatkan umur simpan dan mengurangi kerugian pasca panen.

Salamon, et al. (2004) menjelaskan bahwa daya saing umumnya tergantung pada kondisi ekonomi (harga, biaya, pendapatan, kondisi pasar, subsidi dan serapan) di satu sisi, dan alam (iklim, kondisi tanah, kelembaban) dan kondisi pabrik (jenis pabrik, struktur, penyediaan sumber daya) di sisi lain. Inti dari model ini adalah bahwa keunggulan kompetitif suatu negara dimungkinkan oleh empat corak berkorelasi dari lingkungan ekonomi lokal (Lloyd-Reason dan Wall, 2000). Kumpulan pernyataan yang ditemukan pada keunggulan kompetitif Porter yang dibangun di atas "diamond analysis"nya. Secara khusus, Porter (1990) menegaskan bahwa dalam suatu negara berevolusi melalui serangkaian tahap pengembangan industri, dan untuk setiap tahap, kepentingan relatif dari setiap sudut berlian (diamond) berubah seperti halnya sebuah asal dalam mengingat daya saing industri. Empat tahap, dalam urutan pengembangan, adalah (1) tahap faktor-driven, (2) tahap yang digerakkan oleh investasi, (3) tahap yang didorong inovasi, dan (4) tahap yang digerakkan kekayaan. Porter menjelaskan bahwa hanya dalam tahap yang didorong inovasi, dampak penuh dari empat pilar berlian (diamond) dapat direalisasikan dan keunggulan kompetitif berkelanjutan benar-benar tercapai. Seperti model diamond, pernyataan tersebut bukan tanpa kritik (misalnya Reich, 1990 dalam Davies dan Ellis, 2000), tetapi pernyataan bahwa pembangunan industri dapat berkembang seiring waktu dan bahwa evolusi ini dapat berdampak pada daya saing industri secara internasional adalah panduan yang berguna untuk analisis lebih lanjut dari kasus yang dihadapi.

Dalam hal industri agrowisata kebun belimbing Ngringinrejo yang telah diproses, ada perbedaan tahapan pengembangan industri, dan perbedaan ini dapat mempengaruhi kemampuan masing-masing industri untuk tetap bertahan secara kompetitif karena setiap upaya untuk mengelola tanggapan atau respon terhadap risiko (misanya bencana, wabah penyakit, serangan hama, gagal panen, dll) yang disebutkan sebelumnya. Oleh penilaian penulis sendiri, industri Ngringinrejo telah bergerak ke arah positif, selama kurang lebih lima tahun terakhir dari tahap yang digerakkan investasi ke tahap yang didorong inovasi. Penilaian didasarkan pada hasil pengamatan sebagai berikut: pertama, Ngringinrejo menjadi pemasok produk, baik buah maupun olahan belimbing yang diperhitungkan sebagai investasi signifikan dalam teknologi dan struktur bentuk usaha (koperasi) yang menciptakan dan mempertahankan skala ekonomi dan daya saing lebih besar. Ini adalah dasar dari evolusi industri dari factor-driven ke industri yang digerakkan oleh investasi. Kedua, industri agrowisata belimbing Ngringinrejo, dalam waktu yang lebih singkat, telah 
menghabiskan banyak waktu dan upaya dalam menciptakan kemajuan teknologi inovatif, khususnya dalam penyimpanan dan pengangkutan berskala besar. Inovasi telah memperluas manfaat dari skala ekonomi ke ceruk pemasaran high-end belimbing. Oleh karena itu, melalui inovasi, belimbing Ngringinrejo Bojonegoro yang telah diolah mampu mempertahankan keunggulan kompetitifnya.

Industri olahan belimbing di Ngringinrejo baru memulai sejarah panjangnya dalam hal inovasi, tidak hanya dalam pemrosesan teknologi, tetapi juga dalam pengaturan kelembagaan pada rantai pasokan dan pemasaran bagi konsumen atau pelanggan. Berbagai inovasi ini telah mendukung keunggulan kompetitif industri ini, dan memberikan "budaya" industri serta serangkaian hubungan yang memacu dan mendukung inovasi. Hal yang diyakini bahwa industri agrowisata belimbing Ngringinrejo telah bermigrasi ke tahap perkembangan industri yang digerakkan kekayaan, khususnya dengan ancaman urbanisasi (yaitu, pemilik tanah "menguangkan" dengan menjual kebun belimbing kepada pengembang) dan munculnya selama satu dekade terakhir dari penyebaran struktur kepemilikan yang dicatat sebelumnya. Dengan banyak area produksi kebun belimbing Ngringinrejo sekarang yang dimiliki oleh pemilik yang tidak hadir yang telah berinvestasi di industri sebagai sarana pembangkitan kekayaan, maka pernyataan bahwa industri berkembang ke tahap keempat perkembangan industri Porter tampaknya cukup valid.

Beberapa rumusan strategi generik (terutama strategi fokus) untuk agrowisata kebun belimbing Ngringinrejo antara lain:

1. Membangun kapasitas untuk melaksanakan inovasi dan penelitian di luar peningkatan produktivitas pertanian

Secara tradisional, penelitian pada pertanian telah berkonsentrasi pada peningkatan produktivitas komoditas pertanian. Kapasitas yang rendah pada penciptaan nilai tambah untuk produk pertanian dan pemasaran. Sektor ini juga memiliki rekam jejak yang lemah dalam mencapai kesuksesan inovasi.

Dalam konteks agrowisata kebun belimbing Ngringinrejo, pembangunan kapasitas sebagai upaya inovasi pada dasarnya sudah mulai dilakukan. Hal ini dapat dilihat dari berkembangnya produk olahan belimbing, yang tidak hanya berhenti pada pengolahan sari buah dan sirup belimbing, namun juga untuk pengolahan dodol dan egg roll belimbing. Masyarakat Ngringinrejo secara bertahap (setelah melakukan beberapa eksperimen) akhirnya telah menemukan bahan pokok yang sesuai dengan biaya yang efisien. Permasalahan yang terjadi, lebih mungkin dilihat pada peningkatan kapasitas produksi dan penentuan standar kualitas yang sesuai dengan preferensi pasar. Meskipun area pemasaran sudah semakin meluas, baik ke luar kota maupun ke luar propinsi, namun masih perlu dikembangkan lagi, mengingat kualitas dan varietas belimbing yang lebih unggul.

Dari hasil laporan keuangan agrowisata belimbing Ngringinrejo, menunjukkan bahwa selama tiga tahun terakhir kinerja usaha terus mengalami peningkatan. Penguatan profitabilitas ini akan sangat berpengaruh pada kemampuan agrowisata dalam menjaga 
keberlanjutan bisnisnya. Kolaborasi antara organisasi penelitian, universitas, agribisnis dan pemerintah akan terus didorong, baik untuk membangun kapasitas sumber daya manusia dan menarik pendanaan yang memadai. Pengaturan pendanaan yang cerdas akan dieksplorasi untuk mendorong dana swasta ke daerah ini. Pengaturan inkubasi akan didorong, di mana penelitian dan industri bekerja sama untuk mendorong pengembangan produk. Penelitian harus memperhatikan kebutuhan yang berbeda dari pasar nasional, regional dan global. Penelitian akan fokus pada hal-hal berikut sebagai prioritas: kemitraan dengan perusahaan dan agen nasional; upaya membangun merek yang lebih baik dari produk nasional; mengembangkan dan menerapkan praktik yang baik dalam skema rantai nilai strategis.

2. Membangun wahana wisata artifisial untuk mendukung daya saing dari destinasi Agrowisata Kebun Belimbing Ngringinrejo

Sebagaimana pada strategi diferensiasi produk yang menekankan keunikan suatu produk atau layanan serta upaya untuk membuat produk atau layanan khusus di benak pelanggan, maka aktivitas yang terkait dengan pemasaran akan mendominasi. Semua dari faktor pembebanan memang terkait dengan pemasaran dan menekankan pengembangan atau pemurnian produk dan layanan serta perencanaan untuk pertumbuhan pasar. Dengan mengembangkan inovasi dan kreativitas serta membangun reputasi kepemimpinan teknologi, perusahaan harus yakin akan arus inovasi baru untuk menarik minat pelanggan baru serta untuk memenuhi permintaan pelanggan untuk keunikan yang ada.

Pengembangan wisata alam yang ada di Kabupaten Bojonegoro menggunakan pengembangan pariwisata regional berdasarkan konsep esensial yaitu jarak, aksesibilitas, lokasi, nilai kegunaan, gerakan dan interaksi/interdependensi. Tidak dapat dipungkiri bahwa pengembangan obyek wisata tentunya akan menyerap banyak tenaga kerja lokal. Seperti banyaknya hotel saat ini yang dibangun, juga dapat menyerap banyak tenaga kerja, khususya warga masyarakat Bojonegoro itu sendiri. Tetapi membangun wisata artifisial ini diharapkan dapat mendukung daya saing dari agrowsiata kebun belimbing Ngringinrejo sebagai destinasi wisata yang mempunyai diferensiasi dalam hal nilai produk dan jasa yang ditawarkan kepada wisatawan. Kedepan hal ini diharapkan dapat mendorong peningkatan pangsa pasar yang tinggi untuk agrowisata Blimbing di Ngringinrejo Bojonegoro.

Tentunya meski membangun pangsa pasar yang tinggi juga merupakan praktik strategis yang signifikan untuk strategi diferensiasi, praktik ini memisahkan strategi diferensiasi terpisah dari strategi fokus atau diferensiasi. Tujuan strategi diferensiasi adalah membangun pangsa pasar yang luas, strategi fokus/diferensiasi sangat fokus pada pencapaian target yang lebih banyak. Praktik strategis yang signifikan untuk strategi fokus/diferensiasi termasuk memproduksi produk atau layanan untuk segmen pasar dengan harga tinggi dan menyediakan produk dan layanan khusus. Misalnya, perusahaan mobil seperti Ferrari menggunakan strategi hibrida yakni diferensiasi dan fokus. Keberhasilan Ferrari adalah dari target yang sangat kecil dari mobil yang membeli 
publik yang bersedia membayar untuk kendaraan berkinerja sangat tinggi.

Agrowisata Belimbing di Ngringinrejo Bojonegoro belum dapat menggunakan strategi hibrida ini (diferensiasi dan fokus) tetapi bisa mengimplementasikan satu strategi tersebut yang lepas dari strategi lainnya. Oleh karenanya pengembangan wisata artifisial (buatan) seperti penambahan wahana - wahana, misalnya kolam renang, water boom, dan lain sebagainya dapat mendukung upaya strategi diferensiasi pada Agrowisata Belimbing di Ngringinrejo Bojonegoro.

\section{SIMPULAN DAN SARAN}

Agrowisata kebun belimbing Ngringinrejo Bojonegoro merupakan salah satu kawasan wisata perkebunan yang berlokasi di Desa Ngringinrejo Kecamatan Kalitidu Kabupaten Bojonegoro Jawa Timur. Studi ini didesain untuk mencapai keunggulan kompetitif baik di pasar regional, nasional, maupun internasional. Hasil penelitian mengindikasikan bahwa: 1) Model keunggulan bersaing Agrowisata Kebun Belimbing Ngringinrejo Bojonegoro di dasarkan pada kelima hal utama sebagai determinannya, yakni kondisi faktor (meliputi: iklim, kondisi infrastruktur, lahan, tenaga kerja, daya tarik); kondisi permintaan (jumlah wisatawan domestik, jumlah wisatawan mancanegara, jumlah permintaan pasokan); struktur, strategi, dan persaingan perusahaan (pangsa pasar, struktur tata kelola, strategi promosi); industri terkait dan pendukung (industri hotel dan penginapan, industri restoran dan rumah makan, industri biro perjalanan wisata); dan peran pemerintah. 2) Perbedaan pada masing-masing determinan keunggulan bersaing pada Agrowisata Kebun Belimbing Ngringinrejo memberikan implikasi pada keunggulan yang berkelanjutan (sustainability advantages) yang mendasarkan pada empat dikotomi utama, yakni keterlibatan pemerintah, struktur kepemilikan, pasar (yang dimasuki industri), dan ekspansi dari area lain yang tak terkendali. 3) Rumusan strategi generik yang sesuai bagi agrowisata kebun belimbing Ngringinrejo Bojonegoro adalah strategi fokus, yang berkaitan dengan membangun kapasitas untuk melaksanakan inovasi dan penelitian di luar peningkatan produktivitas pertanian, serta membangun wahana wisata artifisial untuk mendukung daya saing dari destinasi Agrowisata Kebun Belimbing Ngringinrejo.

Studi ini menunjukkan keunggulan kompetitif dan solusi baru untuk industri agrowisata di Indonesia, yakni masing-masing dari empat determinan kompetitif. Namun, itu tidak selalu perlu dimiliki untuk setiap determinan pada tingkat optimal karena satu determinan yang cukup dapat membantu dan memperkuat yang tidak cukup. Oleh karena itu, memiliki empat determinan tunggal yang sempurna itu bisa sama pentingnya untuk membangun sistem self-reinforcing menggunakan berbagai keunggulan kompetitif yang kuat. Sistem yang berfungsi dengan baik memadukan masing-masing penentu sehingga pesaing tidak dapat dengan mudah menyalin seluruh sistem. Untuk pembentukan sistem berlian (diamond system) yang diperkuat sendiri, sebaiknya penguatan merek dan perluasan pangsa pasar bisa menjadi prioritas. Setelah sebuah industri 
mengamankan pasar yang lebih besar (bahkan sampai ke tingkat pasar global), faktor-faktor berlian (diamond) akan menciptakan dinamika, di mana banyak dari tantangan akan dapat dipecahkan. Misalnya, begitu industri memiliki pasar yang lebih besar berkembang secara internasional, ini akan menangkap kebutuhan untuk berinvestasi dalam meningkatkan produksi dan teknologi proses untuk menangani permintaan dalam volume besar dengan cepat dan efisien (faktor, industri terkait dan pendukung, serta strategi, struktur, dan persaingan). Selain itu, industri akan berusaha untuk mencerminkan selera internasional yang beragam konsumen saat mengembangkan produknya (kondisi permintaan). Internasionalisasi industri belimbing akan membuat setiap determinan kompetitif lebih aktif dan akan berkontribusi untuk menciptakan sistem kohesif yang memperkuat diri. Model diamond bersifat dinamis dan menguatkan diri, jika industri terus menantang dirinya sendiri maka dinamika determinan keunggulan kompetitif akan menciptakan sistem yang unik di mana keuntungan dalam skala nasional akan muncul.

\section{DAFTAR PUSTAKA}

Al-Hiary, Masnat, Bashir Al-Zu'bi, dan Amer Jabarin. 2010. Assessing Porter's Framework for National Advantage: The Case of Jordanian Agricultural Sector. Jordan Journal of Agricultural Sciences, 6 (1): 1126.

Antariksa, Basuki. 2011. Peluang dan Tantangan Pengembangan Kepariwisataan Indonesia. Makalah.

Bordas, E. 1994. Competitiveness of Tourist Destinations in Long Distance Markets. Tourism Review, 4 (3): 3-9.

Christou, E. dan Karamanidis, I. 1999. Enhancing Competitiveness in the Hospitality Industry: Revisiting Porter's Generic Competitive Strategies in Greece. The Tourist Review, 54 (1): 42 - 50.

Creswell, John. 2010. Qualitative Inquiry and Research Design Choosing Among Five Approaches. Sage Publication, California. USA.

Davies, H. dan Ellis, P. 2000. Porter's Competitive Advantage of Nations: Time for the Final Judgement?. Journal of Management Studies, 37 (8): 1189-1214.

Dlamini, Bongiwe P, Johann F. Kirsten, dan Micah B. Masuku. 2014. Factors Affecting the Competitiveness of the Agribusiness Sector in Swaziland. Journal of Agricultural Studies, 2 (1).

Dwyer, L., Livaic, Z., dan Mellor, R. 2003. Competitiveness of Australia as a Tourist Destination. Journal of Hospitality and Tourism Management, 10 (1): 60-78.

Dwyer, L. dan Kim, C. 2003. Destination Competitiveness: Determinants and Indicators. Current Issues in Tourism, 6 (5): 369-414.

Goeldner, C. R. dan Ritchie, J. B. 2007. Tourism Principles, Practices, Philosophies. John Wiley \& Sons. USA.

Hassan, S. S. 2000. Determinants of Market Competitiveness in an Environmentally Sustainable Tourism Industry. Journal of Travel Research, 38: 239-245. 
Hill, C. dan Jones, G. 2009. Strategic Management: Theory: An Integrated Approach. Cengage Learning. New York, USA.

Ismayanti. 2010. Pengantar Pariwisata. PT Gramedia Widisarana. Jakarta. Karácsony, Peter. 2008. Analysis of Competitiveness of Hungarian Wheat Sector with Porter's Diamond Model. Journal Central European Agriculture, 9 (3): 399-404.

Kementrian Pariwisata. 2016. Kontibusi Sektor Pariwisata terhadap Pendapatan Devisa Negara. http://www.kemenpar.go.id/userfiles/laporan\%20kinerja\%20kemenp ar\%20 2016_final.pdf. Di akses tanggal 10 Maret 2018.

Kozak, M., Rimmington, M. 1999. Measuring Tourist Destination Competitiveness: Conceptual Considerations and Empirical Findings. Hospitality Management, 18: 273-83.

Lei, D. dan Slocum, J. W. 2005. Strategic and Organizational Requirements For Competitive Advantage. The Academy of Management Executive, 19 (1): 31-45.

Lim, C. 1997. Review of International Tourism-Demand Models. Annals of Tourism Research, 24: 835-849.

Lloyd-Reason, L. dan Wall, S. 2000. Dimension of Competitiveness; Issues and Policies. Cheltenham. UK.

McGehee, N. dan Andereck, K. 2004. Factors Predicting Rural Residents' Support of Tourism. Journal of Travel Research, 43 (2): $131-140$.

Morley, C. 1998. A Dynamic International Demand Model. Annals of Tourism Research, 25:70-84.

Poon, A. 1993. Tourism, Technology and Competitive Strategies. CAB International. Oxon, UK.

Porter, M. 1985. Competitive Advantage: Creating and Sustaining Superior Performance. The Free Press. New York.

Porter, M. E. 1990. The Competitive Advantage of Nations. Mcmillan Press LTD. London.

Porter, M. E. 1997. Competitive Strategy. Measuring Business Excellence, $1(2): 12-17$.

Porter, M. E. 1998. The Competitive Advantage of Nations. The Free Press. New York, NY.

Ribes, J. F. P., Rodriguez, A. R., dan Jimenez, M. S. 2011. Determinants of the Competitive Advantageof Residential Tourism Destinations in Spain. Tourism Economics, 17 (2): 373-403.

Ritchie, B. J. R. dan Crouch, G. I. 1993. Competitiveness in International Tourism: A Framework for Understanding and Analysis. Proceedings of the 43rd congress of the AIEST. San Carlos de Bariloche, Argentina.

Ryan, C. 1991. Recreational Tourism: A Social Science Perspective. Routledge. UK.

Salamon, L. M., Sokolowski, W. dan Associates. 2004. Global Civil Society, Dimensions of the Nonprofit Sector. Volume 2. Kamarian Press. Bloomfield, CT.

Sinclair, T. 1998. Tourism and Economic Development: A Survey. The Journal of Development Studies, 34 (5): 1-51. 
Sterns, James A. dan Thomas H. Spreen. 2010. Evaluating Sustainable Competitive Advantages in Brazilian and U.S. Processed Citrus Supply Chains: An Application of Porter's Diamond Framework. International Journal of Food System Dynamics, 2: 167-175.

Wang, Y. dan Pfister, R. E. 2006. Resident's Attitudes Toward Tourism And Perceived Personal Benefits in A Rural Community. Journal of Travel Research, 47 (1): 84-93. 